УДК 378.091:001.895](477:4)(063)

DOI https://doi.org/10.26661/2522-4360-2021-2-34

\title{
ІННОВАЦЙНИЙ РОЗВИТОК ВИЩОЇ ОСВІТИ В УМОВАХ ТРАНСФОРМАЦІЙНИХ ЗМІН УКРАЇНСЬКОГО СУСПІЛЬСТВА
}

\author{
Гарбуза Т. В. \\ кандидат педагогічних наук, дочент, \\ доиент кафедри сучасних європейських мов \\ Київський національний торговельно-економічний університет \\ вул. Кіото, 19, Київ, Україна \\ orcid.org/0000-0002-2346-5156 \\ t.garbuza@knute.edu.ua \\ Тесленко Н. О. \\ кандидат філологічних наук, дочент, \\ дочент кафедри сучасних європейських мов \\ Київський національний торговельно-економічний університет \\ вул. Кіото, 19, Київ, Україна \\ orcid.org/0000-0002-9556-441X \\ n.teslenko@knute.edu.ua
}

\begin{abstract}
Ключові слова: інновачійний розвиток, інноваційні зміни, соиіальні чинники, иінності освіти, гуманітаризація освіти.
\end{abstract}

У статті в найзагальнішому вигляді сформульована змістовна сутність інноваційних змін освіти у їі соціально-філософському контексті. Проект Концепції розвитку освіти України на період 2015-2025 рр. висвітлює системний характер розвитку освіти, зокрема вищої. Він містить вектори в освітній галузі, за якими затребувані зміни, визначає характер цих змін. Освіта є абсолютно соціальним явищем, і будь-які зміни, потреби, виклики, що стоять перед соціумом, тією або іншою мірою екстраполюються на освітню галузь. Різні освітні процеси потребують змін, якщо виникає значна частина суперечностей. Стаття розкриває соціально-філософське підгрунтя освітніх змін, визначає чинники загального інноваційного процесу в системі освіти в умовах розвитку та окремих викликів українського суспільства. Рушієм педагогічних інновацій, експериментів, реформ постала нова філософська парадигма ціннісних орієнтирів щодо освіти, яка стала не цінністю суспільства, а цінністю особистості. Другим важливим чинником інновацій стало «старіння» знань, що загалом змінило підхід до формування знань, умінь та навичок у системі вищої освіти. Автори статті розглядають низку соціальних перетворень, які більш конкретно формують нові підходи у вищій освіті. Загальні процеси інноваційних змін пов'язані 3 дихотомією «теоретичне навчання-практичні навички», що вилилася в ідею «професіоналізації» вищої освіти. Причому такий фокус змінив і характер гуманітарної підготовки, що має не стільки слугувати формуванню традиційної системи гуманітарних знань, скільки адаптувати iii відповідно до професійних потреб. Не залишилися поза увагою авторів і глобалізаційні процеси, які в епоху карантинних обмежень змінили характер міждержавної освітньої інтеграції, чим загострили питання освітньої конкуренції в новому дистанційному форматі. До соціальних чинників, які визначили автори статті, також належить розуміння інклюзії як відхилення від різних норм, а також етичні питання, що постають перед фахівцями різних галузей. Інноваційний розвиток вищої освіти України можливий лише 3 урахуванням потреб користувача освітніх послуг, а вивчення соціально-філософського підгрунтя дасть змогу спрогнозувати попит на види і форми освітньої діяльності, а також своєчасно реагувати на майбутні виклики. 


\title{
INNOVATIVE DEVELOPMENT OF HIGHER EDUCATION IN UKRAINIAN SOCIETY TRANSFORMATION CHANGES
}

\author{
Harbuza T. V. \\ Candidate of Pedagogical Sciences, Associated Professor, \\ Associated Professor at the Department of Modern European Languages \\ Kyiv National University of Trade and Economics \\ Kioto str., 19, Kyiv, Ukraine \\ orcid.org/0000-0002-2346-5156 \\ t.garbuza@knute.edu.ua \\ Teslenko N. O. \\ Candidate of Philological Sciences, Associated Professor, \\ Associated Professor at the Department of Modern European Languages \\ Kyiv National University of Trade and Economics \\ Kioto str., 19, Kyiv, Ukraine \\ orcid.org/0000-0002-9556-441X \\ n.teslenko@knute.edu.ua
}

Key words: innovative development, innovative changes, social factors, values education, liberalization of education.
The article formulates the substantive essence of innovative changes in education in its socio-philosophical context. The draft Concept of Education Development of Ukraine for the period 2015 - 2025 highlights the systemic nature of education development, in particular, higher education. It contains vectors in the field of education for which changes are required, determines the nature of these changes. Education is a completely social phenomenon and any changes, needs, challenges facing society, are extrapolated to the education sector. Different educational processes need to change if a significant part of the contradictions arises. The article reveals the socio-philosophical basis of educational changes, identifies the factors of the overall innovation process in the education system in terms of development and individual challenges of Ukrainian society. The driving force of pedagogical innovations, experiments, and reforms was, first of all, the new philosophical paradigm of values in relation to education, which became not the value of society, but the value of the individual. The second important factor of innovation was the "aging" of knowledge, which in general changed the approach to the formation of knowledge, skills and abilities in the higher education system. The authors of the article consider a number of social transformations that more specifically shape new approaches in higher education. The general processes of innovative change are connected with the dichotomy "theoretical training-practical skills", which resulted in the idea of "professionalization" of higher education. Moreover, this focus has changed the nature of humanitarian training, which should serve not so much to form a traditional system of humanitarian knowledge, as to adapt it to professional needs. The authors did not ignore the globalization processes, which in the era of quarantine restrictions changed the nature of interstate educational integration, which exacerbated the issue of educational competition in a new distance format. The social factors identified by the authors of the article also include the understanding of inclusion as a deviation from different norms, as well as ethical issues facing professionals in various fields. Innovative development of higher education in Ukraine is possible only taking into account the needs of users of educational services, and the study of socio-philosophical basis will predict the demand for types and forms of educational activities, as well as respond to future challenges. 
Постановка проблеми. На тлі стрімких змін, що відбуваються сьогодні у всіх сферах життя нашого суспільства, виключно важливе значення для досягнення соціально значущих позитивних результатів набуває завдання інноваційного розвитку системи вищої професійної освіти. Інноваційний розвиток вищих закладів освіти являє собою цілеспрямовану діяльність, орієнтовану на кардинальні організаційно-структурні та змістовно-освітні перетворення вишів, що сприяють значному зростанню ефективності їхньої освітньої, науково-технічної та підприємницької діяльності та дають змогу досягти значних науково-технічних і освітніх результатів, істотно впливати на стан і якісний розвиток інноваційної економіки в країні, а також забезпечувати високий ступінь конкурентоспроможності та професійної компетентності випускників вищих закладів освіти. У наші дні для університетів більшості держав Європи, Америки, Японії, Китаю, Сінгапуру, Ізраїлю, Австралії і цілої низки інших країн характерний інноваційний розвиток освіти, зокрема вищої. Вища освіта для країн Заходу $є$ «секретною зброєю», в яку вони інвестують величезні кошти, ретельно розробляють і постійно упроваджують нові технології, а також відстежують конкурентоспроможність. Результатом цього $\epsilon$ ефективне функціонування інноваційної економіки в цих країнах, створення національних інноваційних систем та високий рівень життя.

В Україні відбувається досить суперечливий процес політичних та економічних перетворень в умовах соціальних трансформацій, інтенсивної соціальної стратифікації, перегляду ціннісних засад суспільства. Держава намагається враховувати нові суспільні виклики і сприяти інноваційному розвитку освіти, вищої зокрема.

Серед пріоритетів реформування вищої освіти визначено іiі інноваційний розвиток, який має забезпечити якісні зміни змісту, форм, методів, засобів, технологій навчання, виховання й управління. До першочергових завдань віднесено удосконалення нормативно-правової бази, оновлення змісту вищої освіти, перехід до формування компетентного випускника, створення системи національного виховання, розвиток державно-громадського управління освітою, поліпшення фінансового забезпечення галузі [1].

Водночас стан справ в освіті, темпи та зміст перетворень, що відбуваються у закладах освіти, не повною мірою задовольняють потреби особистості студента, держави та суспільства. Актуальність цієї проблеми зумовлена загостренням суперечностей між:

- потребою держави у компетентному випускникові з відповідним рівнем культури, мобільності, творчості, адаптивності до соціально-еко- номічних змін і недостатнім рівнем усвідомлення нових функцій вищої освіти;

- стихійністю інноваційних процесів у практиці освітньої діяльності закладів вищої освіти й необхідністю узгодження нових ідей із соціальними потребами, нормативними вимогами;

- необхідністю впроваджувати нові знання та використовувати сучасні способи передачі інформації, застосовувати інноваційні освітні технології і низьким рівнем психолого-педагогічної підготовленості педагогів та недостатніми економічними можливостями впровадження нововведень.

Саме тому у проекті Концепції розвитку освіти України на період 2015-2025 років наголошується на необхідності системної реформи вищої освіти на засадах інноваційного розвитку [1].

У вітчизняній і зарубіжній педагогіці кінця XX - початку XXI ст. велика група науковців приділила цій проблемі достатню увагу. Зокрема, iii філософський аспект розроблявся В.П. Андрущенко, Б.С. Гершунським, І.А. Зязюном, В.Г. Кременем, В.С. Лутаєм, В.О. Огневьюком та ін.; соціологічний - М.В. Удальцовою, С.О. Сисоєвою, М.М. Слюсаревським та ін.; управлінський В.І. Бондарем, Л.М. Ващенко, А.С. Гальчинським, Л.І. Даниленко, Г.В. Єльниковою, Л.М. Калініною, В.В. Крижко, В.І. Масловим, М. Месконом, Н.С. Погрібною, М. Портером, Ф. Хедоурі та ін.; педагогічний - К. Ангеловські, Ю.К. Бабанським, В.П. Беспалько, І.Д. Бехом, Л.М. Ващенко, Л.І. Даниленко, I.М. Дичківською, В.І. Луговим, В.Ф. Паламарчук, І.П. Підласим, М.М. Поташником, О.М. Подимовою, I.А.Е. Роджерсом, О.Я. Савченко, Г.І. Селевко, О.В. Сухомлинською, Л.Л. Хоружою; технологічний - А.І. Берг, В.Ю. Биковим, Н.В. Морзе тощо.

Зараз ученими (В.А. Адольф, А.Л. Бірюков, М.В. Волинська, Н.Ф. Ільїн, В.Д. Нечаєв, Н.С. Ладижець, В.С. Лазарєв, Б.П. Мартиросян, Н.I. Лапін, а також Г. Бекер, Е. Брукінг, Дж. Коулман та ін.) розглядаються проблеми створення і вживання інновацій у вищій школі, аналізуються умови ефективного їх функціонування. Водночас спостерігається стихійність процесів створення та впровадження інновацій, відсутність чіткої цільової спрямованості нововведень, неузгодженість інноваційних пошуків, що провадяться в теорії і практиці освітньої діяльності у вищій школі, невідповідність окремих нововведень одне одному, слабкість розроблення інноваційної стратегії розвитку вищої освіти. Крім цього, нині в соціально-філософській літературі немає чіткого розмежування понять, що покликані змістовно відображати інноваційну спрямованість перевтілень, які здійснюються у вищій школі в сучасних умовах $[2 ; 3 ; 4 ; 5 ; 6 ; 7 ; 8]$.

Метою статті $\epsilon$ аналіз феномену інноваційного розвитку вищої освіти у соціально-філософ- 
ському контексті та визначення чинників процесу iii інноваційного розвитку відповідно до сучасних трансформаційних змін українського суспільства.

Виклад основного матеріалу. У сучасній Україні інноваційний розвиток вищої освіти розглядається як процес керованих інноваційних змін іiі компонентів (концептуального, дидактичного, виховного, управлінського, матеріально-технічного тощо) та їхніх структурних елементів, які приводять до якісно нового рівня освітньої діяльності, суттєво поліпшують результати цієї діяльності та забезпечують конкурентоспроможність випускника вишу та викладача як головних суб' єктів інноваційного розвитку освіти.

Особливе значення для інноваційного розвитку сучасної освіти має розуміння іï філософського контексту, який визначає сутність педагогічних інновацій, експериментів, реформ через переосмислення суспільних цінностей освіти. Соціально-економічні реформи початку століття, швидкий темп життя, зміни економічних формацій актуалізували цінності, які деякі вчені називають «аксіологічною революцією». За радянських часів освіта як цінність держави i як цінність суспільства була провідною у педагогічних концепціях. У XXI столітті сутністю освітніх реформ, які відбуваються в багатьох країнах світу, є пріоритет освіти як цінності особистості, «цінності індивідуально мотивованого, пристрасного ставлення людини до рівня і якості своєї освіти» [4].

Більшість дослідників зазначають, «що в сучасному світі діють дві основні діалектично взаємопов'язані тенденції розвитку. Одна з них полягає в зростанні єдності, цілісності людства. Друга - у створенні в світі дедалі більше нових, небачених раніше можливостей для всебічного прояву індивідуальності, для індивідуалізації особистості» [4]. Обгрунтовуючи особистісну цінність освіти, психологи і педагоги підкреслюють, що ресурс розвитку людини закладено в ній самій» [4]. «Імплантація освітніх інновацій є запорукою конкурентоспроможності освіти, iї здатності формувати людину з інноваційним способом мислення» [4].

Другий важливий напрям філософії освіти можна визначити як пошук освітніх ідей, концепцій, систем, на основі яких стане можливим накреслити шлях від ідеї «людини освіченої» до ідеї «людини культури», що означає необхідність надбання особистістю знань не лише для досягнення особистого матеріального успіху, а й для реалізації своїх світоглядних цінностей.

У широкому розумінні поняття «освіта як індивідуальна цінність» скеровує систему освіти не просто на індивідуальний підхід, який би задовольнив здобувача вищої освіти в прикладному, тобто педагогічному форматі, а загалом, як прийнято сьогодні визначати, на індивідуальну траєкторію студента в межах певної освітньої програми, на можливість мобільної трансформації останньої. При цьому індивідуалізація буде змістова, коли суб'єкти вищої освіти зможуть трансформувати систему знань під потреби конкретної особистості.

Викладені філософські ідеї, що, на нашу думку, постають в основі трансформаційних змін, реалізуються в умовах соціального буття і сприяють переосмисленню значущості соціальних процесів у напрямі обов'язкової мінливості освіти, зважаючи на швидке «старіння» знань. Саме в умовах реформування українського суспільства освіта стає одним із провідних чинників його трансформації та розвитку. Водночас на освіту впливають суспільні чинники, що в широкому розумінні сформовані низкою суспільних відносин у різних сферах.

1. Першим, на нашу думку, найбільш потужним чинником, що закладає пріоритети вищої освіти, є перехід від індустріального суспільства до постінформаційного, який можна вбачати в таких важливих процесах:

- формування освітніх цілей із урахуванням все більшої ваги інформації, коли постає потреба у формуванні навичок для орієнтування в інформаційному середовищі та навичок оперування інформацією;

- розуміння системи освіти як системи соціальних послуг і сприйняття освіти як сервісу, що диктує перегляд суспільних відносин між учасниками освітнього процесу з формуванням ролей «надавач освітніх послуг», «отримувач освітніх послуг»;

- «професіоналізація» вищої освіти, зосередженість на професіоналізмі фахівців, коли 3 вишів здобувачі вищої освіти мають вийти вже 3 достатніми для роботи навичками, сформували компетентністний підхід в освіті, зокрема iз серйозною увагою до практичної підготовки. В умовах швидкого «старіння» знань саме компетентністний підхід сьогодні вважається найбільш ефективним для формування майбутнього фахівця;

- гуманізація змісту вищої освіти розглядається в такій управлінській методиці, коли на перше місце висувається здобувач вищої освіти, а процес, що це забезпечує, визначається як студентоцентризм;

- гуманітаризація вищої освіти набула значення не лише в контексті формування всебічно розвиненої особистості, але й у надзвичайно важливому аспекті - це вміння застосовувати різнобічні знання в професійній діяльності;

- тісно 3 попереднім пов'язаний i такий суспільний процес, як формування амбітної особистості з високими комунікативним навичками, яка здатна запропонувати себе на ринку праці. 
Одна 3 важливих навичок, на яку сьогодні звертають увагу науковці, це формування soft skils як однієї з основних компетентностей фахівців, які здатні до комунікації і самопрезентації;

- інформаційний чинник створює умови для диверсифікованих шляхів професійного зростання педагогів, а інформаційна грамотність стає однією з основних навичок педагогів;

- уніфікація процедур оцінювання та оцінок результатів вищої освіти;

- розвиток інноваційних інформаційних технологій [6].

2. Формування професійно орієнтованих знань i навичок нині стало майже гаслом для оцінки всієї освітньої системи.

До сьогодні був популярним підхід, що надмірна «професіоналізація» вищої освіти звужує особистість, зменшуючи гуманітарну складову частину та унеможливлюючи поглиблене вивчення відгалужень різних наук i практик. Складно погодитися 3 таким поглядом, адже зосередження на професійних компетентностях у процесі формування освітніх програм і складників освітніх програм покликано враховувати і професійні, і гуманітарні потреби особистості і фаху, що сприяє якраз інтеграції знань і вироблення навичок їх застосування відповідно до фаху. Таким чином, саме на цей процес найбільше екстраполюється компетентнісний підхід в умовах формувань не самостійних знань із різних наук, а вміння оперувати інформаційним середовищем для отримання знань з різних наук і практик. Заклади вищої освіти переходять на вузькопрофільні, диверсифіковані освітні програми з урахуванням мінливості знань і перетворень на ринку праці.

Особливим для України у цьому напрямі став інститут стейкхолдерства, який, 3 одного боку, дозволяє співпрацювати 3 ринком праці, враховувати його потреби, формувати рекомендації, а 3 іншого - зробив професійне середовище повноправним учасником освітнього процесу. Тим самим у системі сервісу освіти з'явилися контрольно-дорадчі учасники - стейкхолдери - представники ринку праці.

3. Глобалізація як сучасна світова тенденція. Вона впливає на обмін інформацією, трансфер капіталів, загострення планетарних проблем довкілля, інтенсифікацію міждержавних відносин, бізнесу, підприємництва. У цьому ж контексті постають і проблеми розвитку вищої освіти. У глобальному світі ефективність національних освітніх систем освіти розглядається як одна 3 головних передумов забезпечення конкурентоспроможності кожної країни, а відкритість цих систем - як спосіб адаптації молодої генерації до нового світового порядку, запоруки життєздатності національних культур. На виші покладається завдання підготувати молодь до загроз, які становлять для людства індивідуалізм та утилітаризм у крайньому їх прояві, допомогти протистояти їм; навчити їі толерантності та розумінню .

Ще донедавна одним із важливих для глобалізаційних процесів в освіті поставала освітня міграція як здобувачів вищої освіти, так і професорсько-викладацького складу. Пандемічні карантинні обмеження спочатку призупинили цей процес. Сьогодні глобалізація з міграцією не виглядає як фізична міграція і фізичний відтік потенційних i нинішніх здобувачів вищої освіти. Пандемічні обмеження зумовили активний розвиток інформаційних технологій, і насамперед комунікативних, у тому числі освітніх комунікацій. Якщо до цього ми протистояли конкуренції в освітньому середовищі і розуміли, що виїхати зі своєї країни і проживати в іншій країні може обмежена кількість студентів, зважаючи на матеріальну складову частину такої міграції, то 3 розвитком освітніх комунікативних технологій до українських вишів може зменшитися потік студентів, оскільки вже відпала потреба у фізичному пересуванні і тривалому проживанні в іншій країні, а закордонні виші можуть розвивати освітню діяльність у дистанційному форматі. Така ситуація робить нашу освіту більш вразливою, а інформаційні зміни все більш нагальними.

Механізми застосування інформаційних комунікативних технологій, зокрема в дистанційному режимі, викликають і низку етичних питань. Так, наскільки можна дистанціюватися у навчально-виховному процесі, чи $\epsilon$ достатнім вплив викладача на формування студента як фахівця i особистості, якщо «спілкування 3 монітором» переважно однобічне через технічні особливості? Чи можна в таких умовах зробити навчальну дискусію і чи буде вона жвавою і водночас корисною? Адже перенесення «дорослих» практик комунікації в навчальні умови юнацького віку - це не завжди вдала практика. Як необхідно організовувати освітній процес? Як формувати академічні групи? Безумовно, ці питання потрібно вивчати, враховуючи досвід країн, де дистанційна освіта вже має свою історію.

Нині ми можемо констатувати, що практика дистанційного навчання в тих організаційних умовах, що були до карантинних обмежень, неефективна. За результатами опитування, що було проведено серед 55 здобувачів вищої освіти, можна зазначити такі зауваги щодо особливостей дистанційного навчання: значне сповільнення комунікації, практично неможливо вести дискусію, недостатня кількість часу для спілкування $з$ викладачем, значне зменшення відгуків (коментарів) викладачів щодо результатів індивідуально виконаних робіт (навіть консультативні 
години не задовольняють потреб суб'єктів освітнього процесу), неналежні технічні умови. $\mathcal{E}$, проте, й ефективні практики дистанційної форми. До них можна зарахувати: довільне відвідування занять (хоча студенти визначають це як позитивне, проте така характеристика, 3 нашого погляду, досить суперечлива); організація в малих групах наукових заходів - круглих столів, наукових семінарів, немає потреби фронтальної роботи, є можливість самостійно доопрацювати складний тест або завдання, якщо це навчальний захід, а не контрольний, не потрібно багато часу витрачати на дорогу, тому є можливість працювати і ходити в спортивні секціiі. Це основні варіанти відповідей студентів, яких вдалося залучити до опитування. Звернімо увагу, що це зазвичай активні студенти, інші уникали відповіді, адже опитування було запропоновано 123 студентам в умовах «лектор - академічна група». Навіть $з$ останньої тези бачимо, що активність молоді в умовах дистанційного спілкування і навчання значно знижується, що не може не позначитися на якості навчання i соціальних навичках [7].

4. Індивідуалізація культури - це сучасна тенденція, яка поступово поширюється в Україні. У молодіжному середовищі, наприклад, ця тенденція має такі прояви, як лібералізація сексуальних стосунків, зростання самостійності молоді, ролі молодіжних субкультур, розширення прав жінки, посилення уваги до захисту прав дитини, до осіб з особливими потребами. Усе це формує інклюзивний підхід як загалом в освіті, так i у вишах.

Однак, незважаючи на те, що у глобалізованому суспільстві освітні послуги надаються 3 максимальним урахуванням індивідуальних запитів і потреб споживачів, значно зростає соціальне розшарування суспільства, аж до його поляризації: на одному полюсі опиняються обрані й успішні, а на іншому - невдахи та аутсайдери. Навіть у заможних країнах зростає кількість дітей iз функціональними обмеженнями життедіяльності, соціально дезадаптованої молоді, і це значно послаблює канали зміцнення солідарності у спільноті. Цілі, якими керуються за таких умов заклади освіти, постають досить суперечливими: з одного боку, необхідно готувати тих, хто навчається, до економічної конкуренції, виховувати їх як непересічних особистостей, ініціативних і креативних фахівців, а 3 іншого - формувати в них здатність до співробітництва, навчати працювати в групі, виявляти солідарність і дбати про колективний інтерес [6].

5. Прискорення науково-технічного прогресу $€$ тією загальною тенденцією, яку проблематично оцінити однозначно, оскільки сучасні нау- кові відкриття вражають як перспективами, так i загрозами, які вони становлять для людства. Наприклад, експерименти 3 людським мозком, клонуванням, генною інженерією, агротехнології тощо. Практично в кожній галузі постають етичні питання напряму розвитку і надмірності людського втручання. Розвиток тієї чи іншої галузі є як обнадійливим у плані вдосконалення, так і небезпечним в плані руйнації. У зв'язку з цим постає етичне питання, до якої межі можливо втручатися у генофонд людини, робити соціальні експерименти, впроваджувати заходи 3 економії одних природних ресурсів, нехтуючи іншими.

Заклади вищої освіти покликані вирішувати завдання «розумної асиміляції» досягнень науково-технічної революції. Передусім слід навчити студентів замислюватись над наслідками нестримного наукового прогресу, усвідомлювати, що наукові відкриття за жодних обставин не мають розглядатися як самоціль, а виключно як засіб цивілізаційного розвитку людства.

Висновки. Розгляд соціальних та ціннісно-цільових складових частин інноваційного розвитку вищої освіти в Україні відтворюють бачення авторів щодо необхідності зміни основної парадигми вищої освіти відповідно до типу соціокультурного розвитку країни; руху української освіти в напрямі інтеграції до світового освітнього простору (гуманізація освіти, комп'ютеризація, вільний вибір програм навчання); системи вищої освіти відповідно до вимог ринкової економіки. Ці зміни реально можуть бути здійснені за умов забезпечення державою прозорості, широкої гласності під час підготовки та реалізації всіх найважливіших кроків із реформування вищої освіти, реальної участі в ньому найбільш авторитетних фахівців галузі, обов'язкового проведення громадської, насамперед наукової, експертизи найважливіших рішень і проектів у цій галузі.

Освіта повинна дати адекватну відповідь сучасним викликам. Які акценти розставити в координатах освітніх змін?

Це передусім:

- індивідуалізація змістового аспекту вищої освіти, а не лише педагогічного;

- розкриття користі індивідуального і формування відповідальності за власний вибір, активізація свідомого вибору;

- забезпечення повноцінної соціалізації через мобільні структурні зміни у вищій освіти в умовах сучасних викликів;

- екологізація суспільної свідомості, зокрема у професійних етичних питаннях;

- професіоналізація вищої освіти 3 адаптацією до гуманітарних потреб. 


\section{ЛIТЕРАТУРА}

1. Проект Концепції розвитку освіти України на 2015-2025 pp. URL: http://old.mon.gov.ua/

2. Енциклопедія освіти / Акад. пед. наук України ; за ред. В.Г. Кремень. Київ: Юрінком Інтер, 2008. 1040 c.

3. Пшенична Л. Інноваційні процеси в освіті як фактор ії успіху. Педагогічні науки: теорія, історія, інновачійні технології. 2014. № 4 (38), С. 3-16.

4. Сова M.O. Сучасні тенденції інноваційного розвитку університетів України. URL: http:// Kukkit.ru/docs/ts/ no2/4.pdf (дата звернення: 19.03. 2021).

5. Супрун А.Г., Новіцька К.В. Інновації та творчість як основа змін освітньої парадигми. Науковий вісник Національного університету біоресурсів і природокористування Украӥни. Гуманітарні студії. 2015. Bun. 228. C. 97-102.

6. Феномен інновації: освіта суспільство, культура / за ред. В.Г. Кременя. Київ: Педагогічна думка, 2008. $472 \mathrm{c}$.

7. Шмалєй С. В. Проблеми вищої освіти в умовах глобалізації. Педагогічні науки: теорія, історія, інновачійні технологіï. 2019. № 16 (90), С. 273-286.

8. Silver H. Managing to Innovate in Higher Education. British Journal of Educational Studies. 1999. vol. 47. P. 145-156.

\section{REFERENCES}

1. Proekt Kontseptsii rozvytku osvity Ukrainy na 2015-2025 [Draft Concept of Education Development of Ukraine for 2015-2025]. URL: http://old.mon.gov.ua/

2. Kremen, V.H. (Ed.). (2008). Entsyklopediya osvity [Encyclopedia of Education]. Kyiv: Yurinkom Inter. $1040 \mathrm{~s}$.

3. Pshenichna, L. (2014). Innovatsiini protsesy v osviti yak faktor ii uspihu [Innovative processes in education as a factor of its success]. Pedagogical sciences: theory, history, innovative technologies. № 4 (38). P. 3-16.

4. Sova, M.O. Suchasni tendentsii innovatsiinoho rozvytku universytetiv Ukrainy [Modern trends of innovation development of Ukrainian universities]. (n.d.), available at: http:// Kukkit.ru/docs/ts/ no2/4.pdf (Accessed 24 March 2021).

5. Suprun, A.H. \& Novitska K. V. (2005). Innovatsii ta tvorchist yak osnova zmin osvitnoi paradyhmy [Innovation and creativity as the basis of changes in the educational paradigm]. Scientific herald of the National University of Biorezerves and Natural Resources of Ukraine. Humanities Studies. № 228. P. 97-102

6. Kremen, V.H.(Ed.). (2008). Fenomen inovatsii: osvita, suspilstvo, kultura [The phenomenon of innovation: education, society, culture]. Kyiv: Pedagogical thought. 472 p.

7. Shmaley, S.V. (2019). Problemy byschoi osvity v umovah globalizatsii [Problems of higher education in the context of globalization]. Pedagogical sciences: theory, history, innovative technologies. № 16 (90). P. 273-286.

8. Silver, H. (1999). Managing to Innovate in Higher Education. British Journal of Educational Studies. vol. 47. P. 145-156. 